\title{
Charity in Russia: from Alms to "Tax For the Poor" and Back
}

\section{目 Dmitry Komyagin}

Professor, Department of Financial, Tax and Customs Law, Law Faculty, National Research University Higher School of Economics, Doctor of Juridical Sciences. Address: 20 Myasnitskaya Str., Moscow 101000, Russian Federation. E-mail: dkomygin@hse.ru

\section{国目 Abstract}

Social spending is the first-largest spending of the Russian Federation consolidated budget but it still remains insufficient. Such spending was not planned at all in the state list one hundred years ago, and all social insurance was carried out as part of charitable activities. The article presents the evolution of charitable activities from alms to current "humanitarian spending" and shows the prospects and tendencies for its further development. The article covers the history of the origin and concept contents of "state charity", "public charity", "social security", "social protection" and "state social insurance" in Russia. It touches upon the issue of "monetization" of social benefits in Russia in 2004 that have generated a good deal of excitement. In the article, charitable activity is being considered for the first time through the prism of budget expenditures as one of the aspects of public economy. It describes the history of changes in public policy relative to assistance to the poor in the Russian Empire from the $16^{\text {th }}$ century, in the Soviet period till the present time. In addition, the author made assumptions about the prospects of social spending, which is associated with the implementation of such modern ideas at the international and national level, as the concept of human capital development and unconditional basic income. The sources of security of the most complicated system of state and public charity, which was formed in the Russian Empire by the beginning of the $20^{\text {th }}$ century, have been analyzed for the first time. The article examined the idea of the "tax for the poor" that has appeared at the end of the $19^{\text {th }}$ century due to the activity of Konstantin Grot's committee, which is not only a means to ensure expenditures for state charity, but also a logical stage in the consistent development of charitable activities that was interrupted after the Russian Revolution. In addition, it covers the ratio of the "tax for the poor" and modern insurance contributions and the transformation of the purpose of the "tax for the poor".

\section{O-1国 Keywords}

budget, budget spending, social spending, social policy, charity, state charity, social security, social insurance, tax for the poor, compulsory insurance contributions.

Citation: Komyagin D.L. (2018) Charity on Russia: from Alms to "Tax for the Poor" and Back. Pravo. Zhurnal Vysshey shkoly ekonomiki, no 3, pp. 99-121 (in English) 


\section{Introduction}

A new type of social payments will appear in Russia since January 1, 2018 a benefit for families in which the first child was born. It will be paid every month to families, which average per capita income is less than one and half subsistence wages of the able-bodied population in the region, until a firstborn reaches one and half years of age. The national average amount of payment per child will be RUB 10.5 thousands in 2018. The estimated amount of payments will be RUB 144.5 billion in 2018. It is obvious that the amount will grow in 2019 for a total of two years, and if the number of newborns increases, the amount of payments will also increase.

The figures are considerable. At the same time, a new obligation for spending is only one of numerous obligations, which are realized within the framework of the social policy of the state. What is their volume?

According to the Report on the Implementation of the Russian Federation Consolidated Budget and Budgets of State Extra-budgetary Funds for 2015, the amount of money spent under the section "Social Policy" was approximately RUB 10.5 trillion. At the end of 2016, these data (in total) amounted to about RUB 10.1 trillion. This is approximately $35 \%$ of the total spending of the Russian Federation consolidated budget. Spending under the sections "Education" (Budget Classification Code 0700) and "Health Care" (Budget Classification Code 0900) is targeted at observance of constitutional social guarantees. Taking into account these sections, the total amount of spending on social guarantees for citizens will grow to approximately RUB 16.4 trillion, or 55\% of the total amount of spending of the Russian Federation consolidated budget. Both in the former and in the latter case, social spending is the first largest spending of the consolidated budget that exceeds even spending on defense.

It should be added that spending targeted at the assistance to the needy is also planned under other sections of budget spending. For example, provision of equal transport accessibility for benefit recipients (Housing and Utilities section).

The prevailing nature of social spending can be illustrated through the history of benefits "monetization" which resulted in amendments to the laws for benefits and securities guaranteed to citizens by the state, according to Federal Law No 122-FZ of August 22, 2004.

The following citizens whose benefits were affected by monetization (the list is far from being complete) can be called, for example:

different groups of disabled persons, veterans, persons working in the regions of the Far North and equated localities;

military men, employees of law enforcement agencies, public prosecutor's offices, courts, personnel of the penitentiary system, the Ministry of Emergency Situations; donors;

persons with children;

orphans and abandoned children; 
aged persons;

victims of political repressions;

victims of radiation (due to the 1957 accident at the Mayak and discharges of radioactive waste into the Techa River, nuclear tests at the Semipalatinsk Test Site, liquidation of the Chernobyl disaster), etc.

Various benefits were related to public services, travel, holiday, treatment, supply of consumer goods and other special products, medical care, etc.

The appropriate benefits were transformed into various types of social services ${ }^{1}$, which are provided according to individual needs, and (or) into monetary payments (including monthly monetary payments ${ }^{2}$, social benefits, pension supplements, subsidies ${ }^{3}$ ). The specified types of budget spending are provided under the section "Social Policy" (subsections "Social Service for Population" and "Social Security of Population") $)^{4}$.

Accordingly, it should be emphasized that there were no above-mentioned social benefits and payments a century ago, and social spending (state charity) was not planned at all in the list of public expenditures and receipts on a regular basis.

\section{Charity and State Policy}

There is no doubt that the appearance of spending on social policy in budgets (they are also referred to as spending on social security or social protection ${ }^{5}$ ) is directly related to the development of charity, that is true both for Russia and for other states.

${ }^{1}$ According to Chapter 6 of Federal Law No 442-FZ of December 28, 2013 "On the Fundamentals of Social Service in the Russian Federation", the following services may be provided to the needy: household, medical, psychological, pedagogical social services, and assistance in job searching, obtaining legal services, and providing free hot meals or sets of products, cloths, footwear and other basic necessities, temporary housing. According to Art. 6.2 of the Federal Law "On State Social Assistance", social services include medicines, medical products, medical food, vouchers for health resort treatment, journey on suburban railway and intercity transport. See also Federal Law No 122-FZ of August 2, 1995 "On Social Service for Aged and Disabled Persons"// SPS Consultant Plus.

2 Art. 63 of Federal Law No 181-FZ dated November 24, 1995 "On Social Protection for Disabled Persons in the Russian Federation" // SPS Consultant Plus.

3 For example, Art. 1, 12, 12.1 of Federal Law No 178-FZ of July 17, 1999 "On State Social Assistance”; Art. 5-8 of Federal Law No. 159-FZ of December 21, 1996 "On Additional Guarantees and Social Protection for Orphans and Abandoned Children" // SPS Consultant Plus.

4 There was a lot of debate among politicians about "Monetization Act". The main idea of this act was to replace benefits in kind with compensations in cash. It was postulated that after "monetization" the previously achieved level of social protection for citizens will be preserved and will probably increase. The "Monetization Act" has amended the legislation of the Russian Federation in such a way that the terms "benefits", "social protection", "social assistance" have been sequentially replaced by more vague term "social support".

${ }^{5}$ English "social security" is targeted at ensuring a minimum standard of living, below which no one should fall. 
According to the American researcher A. Lindenmeyer, the history of Russian charity is "forgotten Atlantida". This situation is due to the seventy-year prohibition of this subject during the Soviet era. This prohibition resulted from the ideological view that charity is "assistance that is hypocritically given by representatives of the ruling classes to some part of the indigent population in order to deceive the working people and divert them from the class struggle", and in the USSR the "socialist system eliminated indigence, poverty and unemployment".

The organization of private charitable activities was prohibited in Soviet Russia, and for this reason, the actions of the Soviet authorities against the Russian Orthodox Church and international organizations, which attempted to help the starving population in the Volga Region, can be recalled).

Today, there are numerous researches of historical scholars specializing in history of charity ${ }^{8}$, sociologists research this subject ${ }^{9}$, and it is time for researchers in financial law. As mentioned by A. Isaev, “... charity can be discussed from the point of view of economy. Each act of charity is accompanied by the transition of certain benefits, certain property from one to another", that is the subject of sciences researching public economy ${ }^{10}$.

${ }^{6}$ Lindenmeyer A. Otkryvaya Atlantidu. Tendentsii i prespektivy izuchenia istorii rossiysloy blagotvoritelnosti [Discovering Atlantis. Trends and Prospects of Studying the History of Russian Charity]. Blagotvoritelnost' $v$ istorii Rossii. Hovye document $i$ issledovania [Charity in the History of Russia. New Documents and Studies]. Saint Petersburg: Nestor-Istoria, 2008, p. 95.

${ }^{7}$ Bolshaya sovetskaya encyclopedia [Big Soviet Encyclopedia]. 2nd ed. Vol. 5. Moscow: Sovietskaya Encyclopedia Press, 1950. P. 278-279.

${ }^{8}$ In general, the author relied on the following fundamental works of contemporary historical scientists for the history of charity in Russia before the early $20^{\text {th }}$ century: Ulyanova G.N. Blagotvoritelnost' $v$ Rossiyskoy Imperii $v$ kontse 19 - nachale 20 veka [Charity in the Russian Empire in the $19^{\text {th }}$-early $20^{\text {th }}$ Century]. Moscow: Nauka, 2005, 287 p.; Sokolov A.R. Blagotvoritelnost' $v$ Rossii kak mechanism vzaimodeistvia mezhdu obschestvom i gosudarstvom (konets 18-konets 19 veka) [Charity in Russia as a Mechanism of Interaction between Society and the State (early $18^{\text {th }}$ century-late $19^{\text {th }}$ century)]. Saint Petersburg: Nestor-Istoria, 2007, 132 p. These studies reflect somewhat different estimates of the authors but coincide with the determination of the stages and major events during these periods. There are other significant historical works for this subject but they are fragmentary and less informative. In addition, there are detailed works of pre-revolutionary researchers (including lawyers and economists) that were created at the turn of last century and before last century. For detailed study of the historiography of charity, it is useful: Ulyanova G.N. History of Russian Charity in the Coverage of Historiography of the $19^{\text {th }}$ century - early $20^{\text {th }}$ century. 2006. Available at: http://galinaulianova.ru/index.php?option=com_content\&view=article\& $\mathrm{id}=105 \% 3$ Ahistory-blagotvoritelnost $\&$ catid=38\%3Abooks\&Itemid=60\&lang=ru (accessed: 16.06.2016)

9 For example: Baleeva K.I. Voprosy transformatsii traditsionnyh blagotvoritelnyh institutov v istoricheskoi perspective [Issues of Transformation of Traditional Institution of Charity in Historical Retrospective]. Blagotvoritelnost' prosveschenie: Istoria i sovremennost' [Charity and Enlightenment: History and Modernity]. Saint Petersburg 2014; Peshkova N.N. Blagotvoritelnost v Evrope: zabava bogachei ili sposob resheniia sotsialnyh problem? [Charity in Europe: Whim of the Riches or the Way to Solve Social Problems?] // Sovremennaya Evropa, 2014, no 3, pp. 106-115.

${ }^{10}$ Isaev A.A. Blagotvoritelnost' i obschestvennaya blagotvoritelnost' [Charity and Public Charity] // Reformy i zakon, 2016, no 4, p. 40. 
A.R. Sokolov says that the combination of state social insurance and security and private charity is optimal in public life ${ }^{11}$.

It should be noted that the real amount of funds redistributed within the framework of charitable activities will always remain hidden, it cannot be measured accurately, and it can only be guessed. In the author's opinion, the amount is considerable.

Charitable activity in Western Europe and Britain was not interrupted, as in Russia, and is traditionally considered as an effective way to solve social problems. In addition, modern charity concerns not only rich persons but everyone. Sociological literature gives such figures: more than 110 thousand charitable foundations are registered in Europe and from 750 thousand to 1 million persons are employed there, and approximately EUR 100 billion are allocated for the programs of foundations every year.

\section{History of State Charity in Russia}

The development of state charity (public charity) in Russia can be reckoned from the $16^{\text {th }}$ century ${ }^{12}$. Vladimir Gerrier defined public charity as a cultural form of charity ${ }^{13}$. In the Soviet period, the term "state (public) charity" was replaced by the notion of "social security", and such synonym for the notion of social security as "social protection"14 only appeared in the 1990s.

As noted by G.N. Ulyanova, the history of charity in Russia as in other European countries had several stages:

personal alms;

state repressions against professional beggars;

sense of public duty and specialization of charitable activities by types and forms $s^{15}$.

However, as usual, the historical stages are conditional; in general, the development of charity was from "traditional Christian helping the poor" to "secular

${ }_{11}$ Sokolov A.R. Op. cit. P. 645.

12 The term "public charity" was also used in names of different organizations and in public records in the $19^{\text {th }}-20^{\text {th }}$ centuries.

${ }^{13}$ Encyclopedichesky slovar Brockhauza i Efrona [Encyclopedian Dictionary of Brockgauz and Ephron]. Vol. XXV. Saint Petersburg, 1898. P. 165.

${ }^{14}$ Social insurance, which first appeared as workers' insurance in the late $19^{\text {th }}$ century, first in Germany (1889), and then immediately in all other countries of Europe and in Russia, is not mixed with the notion of social security, as it differs in form and sources. At that time (as it is today), the state always subsidized insurance offices. For example, in Germany the insurance office was increased by $60 \%$ from workers' contributions and $40 \%$ from state subsidies.

15 Ulyanova G.N. Zakonodatelstvo o blagotvoritelnosti v Rossii (konets 18- nachalo 20 veka) [Legislation on Charity in Russia (late $18^{\text {th }}$-early $20^{\text {th }}$ century)] // Otechestvennaya istoria, 2005, no 6, p. 78. 
philanthropy"16. Today's situation is characterized by a human inalienable right to receive social assistance and state guarantee corresponding to this right.

\section{Alms and Christian Helping the Poor. «Industrial Beggars"}

The beginning of charity is lost in time. It could be argued that monasteries played initially an important role in the sphere of helping the suffering persons in Russia, and such activity is still one of the most important for them. At the same time, monasteries used not only their own funds but also donations from the tsar and other noble persons. A. Sokolov even states that "until the $15^{\text {th }}$ century, church charity in Russia existed with the tithe of the prince, who transferred (to the monasteries. - D.K.) not a casual, but a permanent income" ${ }^{17}$.

Due to the appearance and development of state (pubic) charity, alms did not disappear but ceased to play an apparent social role.

The beginning of the second stage of charity development in Russia can be traced back to the $16^{\text {th }}$ century, when the state began to organize charity.

Academic literature mentions that information about organized charity in Russia appeared since 1551 that is, due to the decrees of Stoglavy Sobor in the reign of Tsar Joann IV. Attention to charitable activities was also focused in the Code of $1649^{18}$.

However, the attempts of systematic legislative regulation of social assistance should be reckoned from the "social program" of Tsar Fedor Alekseevich that was set out in his decree in 1682. This decree, firstly, created a system of state charity and, secondly, divided the beggars into real beggars and "industrial beggars" or "feigned vagabonds", who should be "separated" from the crippled and wretched persons, and who were prohibited to walk along the streets and were obliged to work $^{19}$.

Another notable attempt of legal regulation of charity (in other words, social security) was made by Tsar Peter Alekseevich (Peter the Great). The issued decrees concerned the admission of the needy, sick and crippled persons in hospitals, almshouses, and "money for food" and the maintenance of military men-veterans. In the development of Fedor Alekseevich's policy, begging (mendicancy) was completely prohibited. As part of the fight against parasites, Peter the Great's decrees ordered, under penalty of fine, not to give alms personally but to send it to

${ }_{16}$ Sokolov A.R. Op. cit. P. 3, 98-99.

17 Ibid. P.107.

18 Sulakshin S.S., Bachurina D.V., Vilisov M.V. et al. Blagotvoritelnost v Rossii i sotsialnaya pomosch [Charity in Russia and Social Service]. Moscow: Yurist, 2013. P. 38.

19 Blagotvoritalnaya Rossia. Istoria gosudarstvemmoy, obschestvennoi i chastnoi filantropii $v$ Rossii [Charitable Russia. History of State, Public and Private Philanthropy in Russia]. P. Lykoshin, ed. Saint Petersburg: Pavlenkov, 1901. P. 89-94. 
almshouses. Monastery departments were put in charge of the poor, and begging was declared as illegal profession. During this period, fines for charitable activities were deducted from dissenters, that is, it can be said on some financial provision of social assistance ${ }^{20}$.

In the period between the reign of Peter the Great and Catherine the Great, the supervision of state charity affairs was transferred from churches, monasteries, and clergy to departments ${ }^{21}$.

Severe laws against physically healthy beggars and vagrants (including the death penalty) existed until the beginning of the sixteenth century in France, Germany and Italy. At the same time, the idea of charity as public duty appeared and began to grow stronger.

\section{Public Duty}

The next (third) stage of the history of state charity in Russia can be reckoned from Catherine the Great's Decree dated the 7th of November 1775 "Institutions for the Administration of the Provinces of the Russian Empire". By this decree, departments of public charity were founded in order to organize and maintain: public schools, orphanages, hospitals, almshouses, houses for terminally ill people, madhouses, workhouses and houses of correction. Departments were founded as part of provincial institutions, it was ordered to involve the best and wealthy people from all classes to manage them and to ensure the sources of their regular financing.

In the reign of Catherine the Great, departments of public charity were opened in 40 provinces $^{22}$.

Less than a hundred years later, provincial departments brought their capitals to RUB 25 million and supervised 524 hospitals, 39 madhouses, 3 almshouses and 45 orphanages and educational houses ${ }^{23}$.

It should be noted that these institutions were founded out of funds received as a result of secularization, since the monasteries were deprived of the opportunity to maintain their charitable institutions, and the state assumed these functions. Another interesting source of funds that was determined for the system of state charity, was percent of capitals (percent of users) ${ }^{24}$. In addition, each department

\footnotetext{
${ }^{20}$ Ibid. P. 24.
}

${ }^{21}$ Ibid. P. 165.

${ }^{22}$ Afanasyev V.G., Sokolov A.R. Blagotvoritelmost' v Rossii: istoriographicheskie aspekty [Charity in Russia. Historiographical Aspects]. Saint Petersburg: Nestor-Istoria, 1998, p. 22; Voronov A.N. Structura blagotvoritelnyh institutov v Rossiyskoy Imperii [Structure of Charitable Institutions in the Russian Empire]. Blagotvoritelnost'v sotsialonoi politike Rossii: istoria and sovremennost' [Charity in the Social Policy of Russia: History and Modernity]. Saint Petersburg: Nestor-Istoria, 2000, pp. 46-51.

${ }_{23}$ Blagotvoriteknaya Rossia... P. 167.

${ }^{24}$ Sokolov A.R. Op. cit. P. 670. 
was initially allocated a certain amount from the state treasury $y^{25}$. Other sources for the departments activities were donations, payments for charity, income from the sale of maps, fines and penalties, percent of judicial contributions ${ }^{26}$. Then, income from profitable institutions (fisheries, hotel yards and others) was added.

Private charity was officially permitted in 1781 .

Later (in the $19^{\text {th }}$ century-early $20^{\text {th }}$ century) public charity widely developed. According to some published data, 19 thousand charitable institutions with a capital of RUB 268 million were in 1902, according to other sources - 11040 charitable institutions, 19108 parish boards of guardians, the calculations of the same period say that 6 charitable institutions were for every 100 thousand inhabitants of the European part of Russia ${ }^{27}$.

In addition, Alexander I's rescript 1802 proclaimed: "It is necessary to look for the miserable in their houses" 28 . This formula is connected with the general liking of the so-called Hamburg or Elberfeld system at that time.

The Hamburg system corresponds to a form of charity such as public guardianship. This form is based on the idea of prevention of begging and preventive assistance to the poor without stopping their ordinary professional activities ${ }^{29}$. In other words, the able-bodied needy people need to be given the opportunity to earn their living.

The idea of guardianship, at the earliest stage, related to the foundation of workhouses, and from the $19^{\text {th }}$ century it was expressed in the "Hamburg system" mentioned above, which Vladimir Gerrier described in details in his extensive dictionary entry ${ }^{30}$. This system derives its name from the activity of the patriotic society in Hamburg at the end of the $18^{\text {th }}$ century that acted on the principle of individualized assistance, when the guardianship of each poor was entrusted to a concrete well-off person. In Hamburg, and later in Elberfeld, the whole community was organized from a city head to a head of areas, districts and sub-districts. No more than four needy families were provided with targeted assistance and direct contact of a guardian and a needy in one sub-district. This system allowed reducing the number of parasites which could not go unnoticed.

However, the reform according to the German model failed in Russia for a variety of reasons but the idea of guardianship was accepted. Under Alexander the First, departments of public charity continued to be opened and new sources of financial support were found for such departments: half of arrears and fines

${ }^{25}$ It was prescribed to grant RUB 15 thousands to each department from the income of the relevant provinces. See: Ulyanova G.N. Blagotvoritelnost'... P. 182.

${ }^{26}$ Blagotvoritelnaya Rossia... P. $191-197$.

27 Sulakshin S.S., Bachurina D.V., Vilisov M.V. et al. Op. cit. p. 57.

${ }^{28}$ Blagotvoritelnaya Rossia... P. 40.

${ }^{29}$ Sokolov A.R. Op. cit. P. 84.

${ }^{30}$ Encyclopedichesky slovar ... Vol. XXV. P. 168. 
for "penalty fees", fines for passports issued to Gypsies (since 1809), church poor box collection (since 1812), percent of turnover of pledge amounts which were allowed to contribute into departments (since 1816), the remains of city incomes in 1821, remains from the sale of announcements to the Senate Printing House. The treasury was put in charge to maintain military men, civil prisoners and inferior employees of state authorities in hospitals of public charity. Other numerous nonrecurrent payments were made to different departments and simultaneously to all departments. In addition, departments of public charity were exempted from duties when buying immovable and inherited (donated) property ${ }^{31}$.

In 1817, there were 51 departments of public charity with incoming capital: RUB 1038,825 from the treasury; with own capital of RUB 10333390 in paper money, 131650 in silver, 245138 in thalers, 10775 in chervonets, 5000 in shares; with external capital of RUB 13589590 in paper money, 167330 in silver 5073 in thalers, 22524 in chervonets. The value of property was at least RUB 5000000 . In general, the own capitals of departments increased from 1810 to 1825 from RUB 6080000 to RUB 24196000 , i.e. almost four times ${ }^{32}$.

Since the 1860's, the development of public charity took the line of decentralization. Departments of public charity consistently lost the functions of management of public schools (since 1782), guardianship of prisons, workers and houses of correction (since 1866). After introduction of a zemstvo, all functions and capitals of departments of public charity were transferred to these zemstvos. Departments remained only in non-zemstvo provinces.

Besides departments and zemstvo institutions, voluntary societies founded by members of the imperial family as private individuals, played a significant role in charitable activity in Russia in the $19^{\text {th }}$ century. The Philanthropic Society was founded in 1802, and in 1816 it was reorganized into the Imperial Philanthropic Society receiving stable financial support ${ }^{33}$.

The Department of Empress Maria ${ }^{34}$ was founded in 1797 and existed at the expense of personal funds of the Empress (50 percent), government subsidies and private donations. The department also received percent of turnovers of the Loan Treasury and Saved Treasury, percent of payments from amusements and theaters and map monopoly. Statistical data for 1909 shows the activities of the institutions of the Empress in general. As of January 1, 126.440 and 25.959 foster children were in St. Petersburg and Moscow Orphanages, respectively. 54.486 hospital patients

31 Blagotvoritelnaya Rossia...P. 194-197.

32 Ibid. P. 202.

33 Up to RUB 100000 every year, according to other data - RUB 35000 (since 1900).

34 Wife of Paul I Maria Fedorovna. Later, the department was headed, under Alexander I, by Empress Elisaveta Alexeevna, under Nicholas I, by Empress Alexandra Fedorovna, under Alexander II, by Empress Maria Alexandrovna, under Alexander III, by Empress Maria Fedorovna, and under Nicholas II, by Empress Alexandra Fedorovna. 
and 550.306 ambulant patients (more than 1.6 million visits) received help in hospitals and clinics in 1909. 5.022 aged persons lived in almshouses and rest houses, 25.128 children lived in children's institutions. 24.748 people received different assistance (housing, lessons, clothes, footwear, firewood, food, money). In 1909, 710.252 persons of both sexes, in total, were under guardianship, and spending on assistance to them amounted to more than RUB 10 million ( 10621240,25$)$. The number of institutions of the Department of Empress Maria was constantly increased: 459 institutions were in 1881, when Maria Fedorovna began to head the department, and more than 1000 in 1902. The amount of capitals was more than RUB 128 million by January 1, 1905, and the annual budget was estimated at least RUB 24 million in the early $20^{\text {th }}$ century ${ }^{35}$. The Imperial Philanthropic Society and the Department of Empress Maria accumulated a considerable immovable property fund, where charitable institutions were located.

In pre-revolutionary Russia, the following institutions, besides the above-mentioned institutions, were involved in charity work: committees on the poor (committees for the analysis and charity for beggars) ${ }^{36}$; parish boards of guardians (the source of their activities was poor box collection or combined books $)^{37}$; the abovementioned charitable funds of zemstvos and cities (out of capital of former departments of public charity) and other ${ }^{38}$.

Numerous state authorities also had social institutions within their structure. For example, even the Ministry of Finance was in charge of temperance societies ${ }^{39}$. Special institutions were founded for charity to the deaf mutes, juvenile criminals, funds were allocated for the fight against prostitution that included search, treatment and other necessary assistance, canteens and the like were opened for people under the patronage of the Grand Duchess Ekaterina Mikhailovna.

By the early $20^{\text {th }}$ century, the issue of compulsory insurance of workers was resolved by the adoption of the Law 1903 "On remuneration of persons, workers and employees, and members of their families, who suffered as a result of an accident at enterprises of factory and mining industry" and of the Law 1912 "On insurance of workers in case of illness and accidents", these duties were put in charge of employers.

${ }^{35}$ Ulyanova G.N. (2006) Imperatritsa Maria Fedorovna v Russkoy blagotvoritelnosti: maternskaya zabota o stredayuschih [Empress Maria Fedorovna in the Russian Charity: Mother Care of the Suffering]. Empress Maria Feodorovna. Life and Destiny. Saint Petersburg: Amphora, 2006, pp. 103-119.

${ }_{36}$ Appeared approximately at the same time with the transfer of functions of departments of public charity to zemstvos.

${ }^{37}$ For example, scholar literature gives a selection for 1901 that 19108 parish guardianships were for 63 eparchies (Afanasyev V.G., Sokolov A.R. Op. cit. P. 45).

${ }^{38}$ Ulyanova G.N. Blagotvoritelnost... P. 208-209.

${ }^{39}$ Simultaneously with the sale of alcohol. 
In general, during the imperial period of Russian history, despite the predominantly voluntary nature, social insurance is distinguished by a significant range and volume but, at the same time, lack of system ${ }^{40}$.

\section{"Tax for the Poor" and Insurance Contributions}

A visible attempt to reorganize public charity in Russia was the activity of Konstantin Karlovich Grot's (1815-1897) committee. The committee was established in 1892 after the strongest famine in 1891-1892, when "organization of assistance was strongly affected due to the absence of permanent charitable bodies in the localities" 41 . The idea Grot was guided by was the thought that "private and governmental activities should mutually supplement each other" ${ }^{\text {"2 }}$. For this purpose, the following tasks were set: determination of the necessary criteria for the right to engage in charitable activities ${ }^{43}$, and the right to receive such assistance, for example, due to age, illness, etc. (rights to charity); determination of sources for charity; arrangement of the system managed by central and local authorities; determination of types and methods of charity and the relevant institutions - workhouses, hospitals, almshouses, shelters, others.

In the course of activities, the Committee developed the following principles for the organization of public charity: the functions of this charity are broader than the functions of private charity, so long as public charity sets the tasks of common wealth in addition to the objects to help poor individuals; help must be for all classes ${ }^{44}$; public charity is a guarantee, which a cultural state gives its citizens (the right to help); besides persons who are unable to work (old persons, children, disabled ones), persons capable for work must have the right to charity but with the requirement of work performance and not as encouragement of parasitism ${ }^{45}$.

The last conclusion was made under criminal statistics of that time (including foreign statistics): a class of proletarians capable for work gave the highest percentage

${ }^{40}$ Authors name twelve authorities being in charge of charity including both state and public organizations. See: Afanasyev V.G., Sokolov A.R. Op. cit. P. 95. Among others, for example, the Department of Empress Maria, the Imperial Philanthropic Society of the Ministry of Internal Affairs, the Holy Synod (for parish institutions). Consideration of all cases relating to charity and public charity was transferred to the competence of the Ministry of Internal Affairs since 1862.

${ }^{41}$ Ulyanova G.N. Blagotvoritelnost'... p. 167; Sokolov A.R. Op. cit. P. 29.

${ }^{42}$ Ulyanova G.N. Op.cit. P. 166.

${ }^{43}$ Certain legislative acts prohibit accepting donations from "vicious" people by that time.

${ }^{44}$ The Charter of Public Charity 1857 provided the principle of class assistance.

45 Vladimir Gerrier drew attention to the fact that during the period of famine in 1891-1892, the government and zemstvos helped the needy villages with bread, which was given on loan, but many workers leaved their places of work and positions, hoping for free bread, not being afraid of loans. G.N. Ulyanova notes the problem of the "pauperized" peasantry in Russia, when the whole villages begged and lived more prosperously than their neighbors-tillers. 
of crimes. Leading criminologists noted that spending on charity "is repaid by saving in spending on prisons" because poverty is one of the factors of criminality ${ }^{46}$.

Due to the death of Konstantin Grot, the committee was dissolved, and the materials were transferred to the newly formed department of the Ministry of Internal Affairs, which began to take into account, in its circulars and practical activities, the "intellectual capital" accumulated by K. K. Grot's committee ${ }^{47}$. The author, for his part, recognizes the indisputable scientific value of discussions and unpublished works of the committee, especially for the tax on the poor. Numerous prominent scientists and public figures of that time took part in the discussions of the committee, among them, for example, K.P. Pobedonostsev, P.I. Georgievsky, I.T. Tarasov, A.A. Isaev, V.I. Gerrier, E.D. Maksimov, D.I. Pikhno, A.S. Okolsky.

The idea of tax for the poor needs was actively discussed since the late $19^{\text {th }}$ century. The following opinions were in the publications of that time: "the only way to acquire sufficient funds (to help the needy. - D.K.) could be a special tax", which was supposed to be collected from employers with more than four employees ${ }^{48}$.

As indicated above, all numerous Russian charitable organizations (tens of thousands ${ }^{49}$ ) were abolished ${ }^{50}$ after 1917 for several years and instead of them the following institutions appeared: the Board for the Protection of Maternity and Childhood (1918), the Fund for the Provision of the Red Army Children (1918), the Committee for Minors (1918) and some other state institutions. Guardianship bodies for the blind and deaf, reorganized in quasi-state bodies, were not included in the liquidated voluntary organizations. The People's Commissariat of State Charity began to carry out state regulation in the sphere of assistance to the needy (1917), later it was reorganized soon into the People's Commissariat of Social Security (1918).

Subsequently, the functions of social security and related allocations were distributed by the authorities responsible for labour relations or health care that is

46 Ulyanova G.N. Blagotvoritelnost'... P. 17-32.

47 Ibid. Ulyanova determines four periods: 1) before the reform 1861, when there was an accumulation of legislative and practical experience; 2) the reform period, during which there was a transition from casual regulation to systematization and codification; 3) Grot's committee work in the 1890s that attempted to draw up the legislation on new principles of assistance to all classes 4) the reign of Nicholas II, when the legislation was developed under new legal conceptions.

48 Sokolov A.R. Op. cit. P. 217.

49 According to the data of 1902, 11040 charitable institutions, 19108 parish boards of guardians, according to the calculations of this period, 6 charitable institutions were for every 100000 inhabitants of the European part of Russia. See: Sulakshin S.S., Bachurina D. V., Vilisov M. V. et al. Op. cit. P. 57.

50 See Regulations on Voluntary Societies and their Unions, adopted by the Resolution of the AllRussian Central Executive Committee and the RSFSR Council of People's Commissars of July 10, 1932, the resolution of the Central Executive Committee and the USSR Council of People's Commissars of January 6, 1930 "On Procedure for the Foundation and Liquidation of Nonprofit Societies and Unions" and of September 27, 1933 "On Production and Commercial Activities and Lottery Work of Voluntary Societies" (USSR Collection of Laws. 1933. No. 61. Art. 362). 
evident even from their names ${ }^{51}$. Funds intended for social (including pension) insurance (whose source was insurance contributions paid by employees and employers) were variously administered by specialized authorities, trade unions, and currently by management bodies of state off-budget funds (the Pension Fund, the Social Insurance Fund, federal and regional funds of compulsory medical insurance). In either case, the bodies administering the social insurance funds were under the control of the above-mentioned ministries.

In the Soviet period of Russian history, there were universal free medical care and universal social insurance. The budget of social insurance was a separate component in the USSR budget. Thus, social spending on social insurance was a part of state budget spending.

The issue of "tax for the poor" received a new life after the USSR dissolution, when the state budget ceased to exist. Compulsory insurance contributions appear now as this tax.

It is admissible determine five stages of appearance and development of compulsory insurance contributions in the Russian Federation.

The first stage (early 1990's-1998) is connected with the formation of state social insurance funds, the determination of obligation for employers to pay insurance contributions. During this period, the insurance contributions were regulated by the tax legislation ${ }^{52}$.

The second and third stages (1999-2001) are connected with the unification of insurance contributions into a single social tax, while maintaining the principle to receive payments separately to each fund.

The fourth stage (2002-2009) is characterized by the introduction of special compulsory insurance contributions - for compulsory social insurance against accidents at work and occupational diseases (paid to the Social Insurance Fund) and compulsory pension insurance (paid to the Pension Fund of Russia) ${ }^{53}$.

The fifth stage (since 2010) is connected with the final abolition of a single social tax and introduction of the obligation for the insured to pay insurance contributions separately to the Pension Fund of Russia, the Social Insurance Fund, the Federal Compulsory Medical Insurance Fund and the Territorial Compulsory

${ }^{51}$ The USSR State Committee for Labour and Social Affairs, the USSR Ministry of Labour and Social Affairs, the RSFSR Ministry of Health and Social Security, the Ministry of Social Protection of the Russian Federation, the Ministry of Labour and Social Development of the Russian Federation, the Ministry of Labour and Social Protection of the Russian Federation.

${ }^{52}$ Clause 8 of the Procedure for the Payment of Insurance Contributions by Employers and Persons to the Pension Fund of the Russian Federation (Russia) approved by Decree No 2122-1 of the Supreme Council of the Russian Federation of December 27, 1991 «Issues of the Pension Fund of the Russian Federation (Russia)» // SPS Consultant Plus.

${ }_{53}$ Federal Law of December 15, 2001 No 167-FZ “On Compulsory Pension Insurance in the Russian Federation" in the original version // SPS Consultant Plus. 
Medical Insurance Fund. This period is characterized by a complete transition from tax principles to insurance principles of payments.

One can assert that at the present moment there is the sixth stage of development of legislation for insurance contributions due to the fact that the regulations on compulsory insurance contributions were included again in the Tax Code of the Russian Federation (hereinafter referred to as the Tax Code of RF) in 2016 as independent (after taxes and dues) compulsory payments ${ }^{54}$.

It is worth noting such topical issue as the purpose of insurance contribution in comparison with the "tax for the poor".

However, it should be noted that insurance of workers (from the end of the $19^{\text {th }}$ century in Germany first and then in other countries of Europe and in Russia) and state charity (in Russia from the end of the $18^{\text {th }}$ century) developed separately from each other as independent areas of public activity. The evolution of state charity led to the idea of "tax on the poor", and the development of insurance of workers led to the appearance of social insurance funds. Today, in Russia both these ideas are combined in insurance contributions, which must be paid by employers and individuals.

According to common opinion represented in the academic literature insurance contributions are to separate from taxes for a number of criteria, the main of them are purpose, personification and individual refundable nature.

According to the Art. 8 of the Tax Code of the Russian Federation, a tax is a compulsory and individually non-refundable payment which is collected from organizations and individuals by means of the alienation of monetary resources which belong to them on the basis of the right of ownership for the purpose of financing the activities of the state and (or) municipalities.

The Constitutional Court of the Russian Federation determined in its Decision of November 11, 1997 No. 16-P that the purpose of tax collection is "to cover expenses of public authority" 55 .

Social security, as shown above, is one of the purposes of public policy and is provided by significant budget expenditures. That is, the public purpose of taxes and insurance contributions is the same.

What is the difference? Literature determines that insurance contributions are "material guarantee of state pension security for persons when they are deprived of the opportunity to have earnings (income) or lose it due to age, state of health and for other reasons which are considered as insurance risks and grounds for state pension security"56.

${ }^{54}$ Federal Law No 243-FZ of 03.07.2016 "On Amendments to Part One and Two of the Tax Code of the Russian Federation" // SPS Consultant Plus.

55 Bulletin of the Constitutional Court of the Russian Federation, 1997, no 6, p. 4.

${ }^{56}$ Gritsenko V.V. K discussii o pravovoy prirode vznosov na sotsialnoe straxovanie [On Legal Nature of Insurance Contributions]. Bulletin of Saratov State Academy of Law, 2015, no 4, p. 227. 
Therefore, one of the main signs of insurance contributions is called their personification. That is, as opposed to taxes, insurance contributions are not depersonalized but should be accounted on individual personal accounts of each insured person for the further payment, for example, the payment of pension. It should be noted that the payment of taxes is shown in a special personal taxpayer's account, which is operating today in the same regime as an individual pension personal account. Insurance contributions paid as well as taxes are depersonalized in public monetary fund $s^{57}$ and used for the purposes determined by the legislation.

It is noted that insurance contributions are calculated and payable not in order that insured persons can perform specific activities but in order that working persons can accumulate future old-age pensions, and in order to ensure payments in case of occupational accidents and diseases". This can be called a sign of individual refundable nature of insurance contributions and, of course, this will distinguish them from non-refundable taxes. However, is the payment of insurance contributions really refundable? The prospect of pension-age increase has aggravated this problem. Unfortunately, many persons may not exercise their rights to receive pensions. The amount of granted payments is not directly related to the amount of contributions paid (there is a minimum amount), but depends more on other factors: age, employment period, nature of employment. Accumulated insurance contributions are not inherited, not transferred, and not alienated. It cannot be said that the payment of insurance contributions causes a counter-obligation of the state to grant pensions. The payment of insurance contributions is rather one of the conditions for granting a pension. It should be emphasized once again that the amount of insurance contributions paid does not correlate with the amount of further social payments. It is only the realization of the principle of solidarity between generations, which may be an issue.

In general, there are a lot of arguments against the refundable nature of insurance contributions. Giving refundable nature to insurance contributions is still only one of the possible prospects for their development.

Thus, according to Russian practice, there is no much difference between insurance contributions and taxes. For this reason, it can be noted that the "tax on the poor" discussed at the end of the $19^{\text {th }}$ century, insurance of workers appeared at the same time and modern insurance contributions are interrelated.

Let us now consider the purpose of the "tax for the poor needs". This purpose follows directly from its formulation. That is, the purpose of that tax was not related to the idea of individual refundable nature and personalized payments. The tax itself was purpose, and the ground to establish the tax was an idea of philan-

57 Today, there are three: the Pension Fund of the Russian Federation, the Federal and Territorial Funds of Compulsory Medical Insurance and the Social Insurance Fund. There is a high probability that the Social Insurance Fund and the Federal Fund of Compulsory Medical Insurance will be abolished as separate financial institutions and will be included in the federal budget. 
thropy and public security. The idea of individual refundable nature of insurance contributions forces to recognize that the predominant motivation for their establishment is individual material interests, and this is disputable.

\section{Humanitarian Spending and New Monetization}

A. Isaev emphasized the obvious fact - a society cannot be built under the principles of selfishness (or it breaks up into atoms - separate individuals) ${ }^{58}$.

There are opposite opinions (regarding state charity): “... the state is guided not so much by moral considerations of compassionate assistance to the neighbor, human justice, as by requirements of security and tranquility, "by preventing and stopping" 59 .

Christian doctrine played a decisive role for the appearance and development of charitable activities in Russia and the countries of Europe and America. O.A. Chernega notes that charity as social phenomenon originated in the bowels of the Christian Church and the first charitable institutions acting as Latin piae causae were church organizations. However, this author notes that elements of state charity existed until the $1^{\text {st }}$ century AD in ancient Rome, where alimenta of Emperor Nerva (96-98) that represented charity funds for orphans and children of poor parents, existed along with the traditional alms. Such charity as opposed to Christian charity had non-religious, secular nature ${ }^{60}$.

Christian commandments in aggregate represent the doctrine of doing good. One of the evangelical commandments says: "Blessed are the merciful, for they shall obtain mercy" (Matthew 5: 7). The Lord Jesus Christ identified himself with all suffering persons by evangelical words: "For I was hungry and you gave me food, I was thirsty and you gave me drink, I was a stranger and you welcomed me, I was naked and you clothed me, I was sick and you visited me, I was in prison and you came to me" (Matthew 25.35).

Early Christian charity was expressed not only in the verbal preaching of mercifulness but also in that Christians made donations for the needy during divine services. In the course of time, Christian divine services became public and stips were modified into ablutio - weekly donations of celebrants and other wishing persons to the community charity fund ${ }^{61}$.

Today, there is the process of transformation of the idea of Christian assistance to the neighbor into "secular philanthropy" or - into "humanitarian spending",

58 Isaev A.A. Blagotvoritelnost' and obschestvennaya blagotvoritelnost'... P. 40.

59 Belyatskin S.A. Voina i gosudarstvennaya compensatsia uscherba [War and State Remuneration of Losses]. Petrograd, 1915. P. 13.

60 See: Chernega O.A. Pravovaya model blagotvoritelnyh organizatsiy [Legal Model of Charity and Charitable Organizations]. Doctoral Law Thesis Summary. Moscow, 1998. P. 29.

61 Ibid. 
which is no longer based on the fulfillment of the evangelical commandments. This visible difference is, for example, for the implementation of laws on euthanasia in the countries of Western Europe. In particular, the deprivation of charitable status threatens the Swiss nursing home belonging to the Christian organization Salvation Army if it does not apply euthanasia for its patients. Another example (in Belgium): euthanasia for children, it has the specific wording "mercy killing". It is obvious that the Christian doctrine and assistance in suicide (certainly killing) are incompatible with each other.

What tendencies in the development of spending on social policy can be noted? It seems that it combines the influence of several factors: the integration of foreign practices through international institutions; economic or other ideas (often radical), taken for implementation; the general evolution of culture and society in general.

It can be assumed that the transformation of charity towards "secular philanthropy" is accompanied by a change in the objective notions of "poverty".

By the end of the $19^{\text {th }}$ century, poverty was determined as a chronic lack of satisfaction of the most urgent needs, which are obvious. This is food, clothing, and housing. "The person who cannot be above this limit, that is, who is deprived of means to satisfy the most urgent needs is poor. In the opinion of E. Munsterberg, such everyday state of lack of satisfaction of the most urgent needs is the essence of the concept of "poverty" 2 . Extreme poverty was called beggary.

Later, poverty has been already determined relative to the general standard of living in society, as a condition when "normal living and existence of living conditions, which are habitual or at least encouraged or accepted in society, becomes impossible" 63 .

And then, poverty began to be determined by statistical methods according to the norms that are associated with a minimum consumer basket or the cost of living ${ }^{64}$.

Today, it became clear the tendency when the subjective criterion associated with the dignity and development of a person, the level of his satisfaction is also used to determine the poverty threshold. Article 7 of the Constitution of the Russian Federation states that the purpose of social policy of the state is to create conditions to ensure a decent life and free development of any person.

Some information can be obtained from the jurisprudence of the European Court of Human Rights (hereinafter EHCR).

${ }^{62}$ See: Shiryaeva S.V. Bednost' kak sotsialnyi i pravovoy fenomen v trudah russkih yuristov kontsa 19 veka [Poverty as a Social and Legal Phenomenon in the Writings of Russian Lawyers of late $19^{\text {th }}$ Century] // Problems of Russian Statehood: Issues of History, Theory and Practice, 2010, no 1, pp.16-19.

${ }_{63}$ Townsend P. Poverty in the United Kingdom. Harmondsworth, 1979; Mikhalkina E.V. Poverty as a Phenomenon of Post-reform Social Development - Methods of Measurement and Evaluation // Economic Bulletin of Rostov State University, 2005, no 4, p.12.

${ }^{64}$ Mikhalkina E.V. Op. cit. P.14. 
In particular, the ECHR is currently confidently defending the human right not to a minimum amount of benefit but to an amount not abasing human dignity ${ }^{65}$. According to judicial practice, an insufficient amount of pension can be considered within the meaning of the European Convention on Human Rights (hereinafter referred to as the Convention) $)^{66}$, which prohibits inhuman or degrading treatment ${ }^{67}$. At the same time, the ECHR takes the position that the Convention does not guarantee economic and social rights as such ${ }^{68}$.

It is interesting that the ECHR refers the right to receive social assistance to the property rights (including and not for citizens) and non-payment of benefits means even a violation of property rights ${ }^{69}$ in combination with making insurance payments.

The notion of "humanitarian spending" (as opposed to spending on charity) introduced in this article is dictated by the use of the economic term "human resource" in lawmaking ${ }^{70}$. Social spending (social security, social protection and social insurance) is treated as investments in human capital (resource). For example, human resources were recognized as a key factor in the development of the national economy in the USA at the end of the last century that means reorientation of social assistance programs from traditional forms to "promoting the development of each person and groups"

This means the following: if charitable donations mean a living person as ultimate goal and sense of such activities, then the motivation for investing in human capital is not philanthropy but the Protestant ethic described by M. Weber and certainly not human, rational choice of G. Becker ${ }^{72}$.

He notes in his Nobel lecture that "Specialists from fields that do consider social questions, i.e. sociologists, lawyers, political scientists, historians, are often attracted to the economic way of modeling behavior because of the analytical power provided by the assumption of individual rationality" (Becker, 2003: 608). Indeed, G. Becker's calculations provide support for solutions in many situations. For ex-

${ }^{65}$ It corresponds to the goal of state policy provided in the first part of Art.7 of the Constitution of the Russian Federation for the creation of conditions ensuring a decent life and free human development.

${ }^{66}$ The Convention for the Protection of Human Rights and Fundamental Freedoms was ratified by Federal Law No 54-FZ of March 30, 1998 "On Ratification of the Convention for the Protection of Human Rights and Fundamental Freedoms and its Protocols"// SPS Consultant Plus.

${ }^{67}$ ECHR Case Larioshina v. Russia (56869/00).

${ }^{68}$ ECHR Case Pashenko v. Latvia (40772/98).

${ }^{69}$ ECHR Case Gaygusuz v. Austria (17371/90), Koup Poirrez v. France (40802/98).

${ }^{70}$ Lebedeva L.F. SSha: gosudarstvo i sotsialnoe strahovanie. Mechanism regulirovania [USA: State and Social Security. Mechanism of Regulation]. Moscow: Nauka, 2000, p.17.

71 Ibid.

${ }^{72}$ See: Becker G. Ekomonicheski analiz povedenia cheloveka [The Economic Approach to Human Behavior]. Moscow: State University - Higher School of Economics Publishers, 2003. 672 p. 
ample, according to his calculations, investments in education of employees are acceptable when an employee (a corporate employee) receives a highly specialized qualification that does not expand the possibilities for his employment. It is obvious that otherwise there is a leak of trained personnel.

But sometimes Becker's opinions are unexpected. For instance, his assertion that rational choice is applied to all markets including the bride market. It is surprising that Becker, using the model of rational choice and mathematical technique, moves from analyzing economic phenomena to others, for example, family phenomena. The application of the idea of rational choice is accepted here through the evolution (change) of the family ${ }^{73}$.

It is the author's opinion that the development of each person is the main purpose of its existence. However, the danger is that the purpose of his social construction is often suggested instead of human development. In the first half of the $20^{\text {th }}$ century, two programs for the creation of a "new man" were implemented: due to manipulations aimed at the genepool (in Nazi Germany) and due to controlled change in the social order (in the Soviet Union). It can be said that today both projects are still in progress not so radically but worldwide. The first direction of human construction through the achievements of biogenetics is accompanied by attention from experts in bioethics. But there is another, social human construction, not in the framework of biogenetics, but related to the implementation of economic concepts, in particular, the development of human capital. These ideas began to penetrate into the legislation from the beginning of this century.

The term "human capital" remains undetermined - it is unclear whether it is the person himself, or this person is only the bearer of some nonmaterial benefit?

Works appeared for a long time allow calculating human capital by a set of certain indicators (Mincerian equations) and giving certain specific recommendations on capital investment for a private corporation on a microlevel first and then for the government. Thus, the idea of calculating human capital broke its way from theory to practice; the next key question is the set of indicators that should be used in the calculation. Today, in the conceptual field of human capital includes the worldview (for the correct formation of preferences) in addition to education, professional development, medicine, health, nutrition and other similar indicators. The very notion of the development of human capital was combined with the concept of the knowledge economy, which increased its popularity and made the guiding idea in the documents of international organizations ${ }^{74}$.

${ }^{73}$ However, according to Becker's own opinion, this step cost him considerable energies, time and intellectual tension. It should be noted that the demonstration of "boundless" opportunities for economic analysis brought him fame.

${ }^{74}$ See, for example, United Nations Human Development Report 2016: Human Development Report for Everyone. N.Y., 2016. 
The purpose of human improvement evokes in memory the horrors of social experiments in $20^{\text {th }}$ century, the policy of racial selection in the framework of the theory of eugenics in addition to humanistic ideas in pedagogy. It is to be hoped that such lessons have been learned.

Despite the above-mentioned, the example of the United States in the field of social security has many positive features. For example, there are two social security functions in the United States: satisfaction of basic needs (measures against poverty) and compensation for lost income (that is, maintaining of a standard of living). Despite the fact that private and professional social insurance funds prevail in the United States over other states, old age is ceased to be a synonym for poverty there ${ }^{75}$.

The issue of migration, in general, and the limits of social security for migrants, in particular, currently became topical. This problem became a factor influencing the development of spending on the implementation of social policy.

The right of migrants to social security were recognized long ago by International Labor Organization (ILO) Conventions, which stipulate that migrant workers enjoy social protection and benefits no less than workers living in areas of employment ${ }^{76}$; the state is obliged, without discrimination, to grant to immigrants conditions not less favorable than those enjoyed by own citizens ${ }^{77}$. The European Union Acts also provide the same ${ }^{78}$.

Waves of migrants that continue to shake the EU countries raise the issue of admissibility of social payments to the so-called "economic migrants", i.e., to those, who arrived not for work but in search of better life. "Buying loyalty" through the payment of benefits to these migrants leads to the opposite result. This means just another blow to the concept of the welfare state that implies widespread social security and insurance.

Accordingly, it will be recalled one of the critics of Milton Friedman's conception, who proposed (with regard to the United States) to reform the social security system by replacing "the ragbag of specific welfare programs with a single comprehensive program of income supplements in cash - a negative income tax linked to the ordinary income tax" and "to curtail the social insurance system without a refusal to fulfill current obligations, that will gradually force people to be concerned of their own future"79.

${ }^{75}$ Lebedeva L.F. Op. cit. P. 31, 33, 62, 91.

${ }^{76}$ International Labor Organization Convention No. 117 "On Basic Aims and Standards of Social Policy". Geneva, 1962.

77 ILO Convention No 97 “On Migrant Workers”. Geneva, 1949.

78 The European Code of Social Security (1964), the European Social Charter (1961).

79 Friedman M., Friedman R. Free to Choose: A Personal Statement. Moscow: Novoe izdatelstvo, 2007. P. 141. 
The idea of negative income tax is a radical idea ${ }^{80}$ that can be illustrated by the following quote: "it (a negative income tax. - D.K.) will be universal because it will provide assistance to the recipient not because the recipient is an old, incapable or sick person or lives in a certain locality, or has one of many specific features that give the right to receive benefits under one of the existing programs. Assistance will be provided because that recipient has a low income"s1.

It appears that it is not necessary to help people in real need (old persons, sick persons, and mothers), and it sounds cynical. Nevertheless, the idea of introduction of an unconditional basic income is developing and getting stronger (although it has little prospects) and it almost coincides with the proposal of Friedman ${ }^{82}$. Basic income is a unified and single social benefit paid to all citizens, regardless of their needs and employments. In other words, an unconditional basic income is not specific or targeted. The referendum on the introduction of an unconditional basic income gave a negative result in Switzerland but experiments are conducted in some countries both by state and private institutions.

Thus, there is another tendency in the development of spending on social policy that can be called as ultra-monetary or "new monetization" when returning to the beginning of this work.

\section{Conclusion}

A long history, which is connected with the evolution of charitable activities, preceded the appearance of such spending in the section structure of the classification of budget spending. The initial alms or Christian helping the poor, after the period of state repressions against beggars, was gradually transformed into awareness of public duty and public charity, and the state began to play the leading role in the organization of public duty and public charity.

As a result, various types and forms of widespread charitable activities developed in Russia by the end of the $19^{\text {th }}$ century. Sources of these activities were various: donations, direct payments from the treasury, percent of capitals, court deposits and turnovers of pledge amounts, payments for charity, income from the sale of maps, some fees, penalties, income from own enterprises, a part of arrears, poor box collection and collection according to subscription lists, numerous nonrecurrent payments. Almost all activities similar to modern health care, social security and, in part, primary education, was carried out through private initiative.

${ }^{80}$ Another radical idea proposed by M. Friedman was the legalization of drugs within the framework of the concept of "freedom to choose" defended by him.

${ }^{81}$ Friedman M., Friedman R. Op. cit. P. 143-144.

${ }^{82}$ Declaration calling for the introduction of basic income was promulgated at the World Economic Forum in Davos in 2016 on behalf of robots in order to attract attention. Available at: http://www.grundeinkommen.ch/wef-roboter-fuer-grundeinkommen/ (accessed: 02.11.2016) 
The idea of "tax for the poor people needs" arose in the course of search for new funds and is currently implemented in compulsory insurance contributions as independent (after taxes and fees) form of compulsory payments.

In the Soviet period, the issue of charity was consigned to oblivion but today it can and must be raised again and studied not only from the point of view of history and sociology but also from the point of public economy in so far the redistribution of national resources is concerned. Accordingly, the experience of regulation of public charity that connected with the activities of Konstantin Grot's committee may be in demand.

The amount of funds redistributed through charitable activities cannot be called insignificant. Such funds are drawn from the same source from which budget revenues and state credit are derived, that is, from the national income, and this indicates a significant potential for the development of charitable activities.

Social security and charity are components of a single state social policy today, and the prospect of their development has several directions dictated by the integration of foreign practices through international institutions; the introduction of economic concepts; the overall evolution of culture and society.

Today, the right to receive social assistance is property right, and its violation can be treated as a violation of property right. There is a marked trend to transform social spending into "humanitarian spending", which is based not on the fulfillment of the evangelical commandments but on economic ideas.

The idea of introduction of unconditional basic income is one of the potential ways to change spending for social security. This way is not promising and can be described as the next stage of the recent monetization of benefits in Russia; the results of this monetization were no more successful than the results of privatization in the 1990s.

\section{O-1国 References}

Afanasyev V.G., Sokolov A.R. (1998) Blagotvoritelmost' v Rossii: istoriographicheskie aspekty [Charity in Russia. Historiographical Aspects]. Saint Petersburg: Nestor-Istoria, 316 p. (in Russian)

Becker G. (2003) Ekomonicheski analiz povedenia cheloveka [The Economic Approach to Human Behavior]. Moscow: State University - Higher School of Economics, 672 p. (in Russian)

Blagotvoritalnaya Rossia. Istoria gosudarstvemmoy, obschestvennoi i chastnoi filantropii v Rossii (1901) [Charitable Russia. History of State, Public and Private Philanthropy in Russia]. P. Lykoshin, ed. Saint Petersburg: Pavlenkov, 112 p. (in Russian)

Friedman M., Friedman R. (2007) Free to Choose: A Personal Statement. Moscow: Novoe izdatelstvo, 356 p. (in Russian)

Grigoryev I.V. (2008) Sotsialnoe strahovanie trudiaschihsa migrantov v Rossii: pravovye voprosy [Social Security for Migrant Workers in Russia: Legal Issues]. Ekaterinburg: University, 201 p. (in Russian) 
Gritsenko V.V. (2015) K discussii o pravovoy prirode vznosov na sotsialnoe strahovanie [On Legal Nature of Insurance Contributions]. Bulletin of Saratov State Academy of Law, no 4, p. 227.

Isaev A.A. (2016) Blagotvoritelnost' i obschestvennaya blagotvoritelnost'[Charity and Public Charity]. Reforms and Law, no 4, $133 \mathrm{p}$.

Lebedeva L.F. (2000) SSha: gosudarstvo i sotsialnoe strahovanie. Mechanism regulirovania [USA: State and Social Security. Mechanism of Regulation]. Moscow: Nauka, 301 p. (in Russian)

Lindenmeyer A. (2008) Otkryvaya Atlantidu. Tendentsii i prespektivy izuchenia istorii rossiysloy blagotvoritelnosti [Discovering Atlantida. Trends and Prospects of Studying History of Russian Charity]. Blagotvoritelnost' $v$ istorii Rossii. Hovye document $\mathrm{i}$ issledovania [Charity in the History of Russia. New Documents and Studies]. Saint Petersburg: NestorIstoria, $436 \mathrm{p}$.

Sokolov A.R. (2007) Blagotvoritelnost' v Rossii kak mechanism vzaimodeistvia mezhdu obschestvom i gosudarstvom (konets 18-konets 19 veka) [Charity in Russia as a Mechanism of Interaction between Society and the State (early $18^{\text {th }}$ century-late $19^{\text {th }}$ century)]. Saint Petersburg: Nestor-Istoria, $132 \mathrm{p}$.

Sulakshin S.S., Bachurina D.V., Vilisov M.V. et al. (2013) Blagotvoritelnost v Rossii i sotsialnaya pomosch [Charity in Russia and Social Service]. Moscow: Yurist, 370 p. (in Russian)

Ulyanova G.N. (2005) Blagotvoritelnost' v Rossiyskoy Imperii v kontse 19 - nachale 20 veka [Charity in the Russian Empire in the $19^{\text {th }}$-early $20^{\text {th }}$ Century]. Moscow: Nauka, 287 p. (in Russian)

Ulyanova G.N. (2005) Zakonodatelstvo o blagotvoritelnosti v Rossii (konets 18 - nachalo 20 veka) [Legislation on Charity in Russia (late $18^{\text {th }}$-early $20^{\text {th }}$ century)]. Otechestvennaya istoriya, no 6, pp. 78-97.

Ulyanova G.N. (2006) Imperatritsa Maria Fedorovna v Russkoy blagotvoritelnosti: maternskaya zabota o stredayuschih [Empress Maria Fedorovna in the Russian Charity: Mother Care of the Suffering]. Empress Maria Feodorovna. Life and Destiny. Saint Petersburg: Amphora, 245 p. (in Russian)

Voronov A.N. (2000) Struktura blagotvoritelnyh institutov v Rossiyskoy Imperii [Structure of Charitable Institutions in the Russian Empire]. Blagotvoritelnost' v sotsialonoi politike Rossii: istoria and sovremennost' [Charity in the Social Policy of Russia: History and Modernity]. Saint Petersburg: Nestor-Istoria, 187 p. (in Russian) 